\title{
RESERVE PLANNING ON PRIVATE LAND HOLDINGS OF THE FORESTRY COMPANY, STORA PORT HAWKESBURY LIMITED: CAPE BRETON ISLAND AND EASTERN MAINLAND NOVA SCOTIA
}

\author{
CHRISTOPHER A. MILLER \\ Wetlands Research Centre and Department of Biology, \\ University of Waterloo \\ Waterloo, Ontario, Canada \\ N2L 3G1
}

\begin{abstract}
The forestry company, Stora Port Hawkesbury Limited, owns 280 properties throughout Cape Breton Island and eastern mainland Nova Scotia with a total cumulative area of 24590 ha. This study utilized a coarse filter analysis to determine which of these land holdings support representative and outstanding natural features compatible with the creation of a system of privately-owned nature reserves. Aerial photographs were used to document each property. Approximately $35 \%$ of the private land holdings were caught by the coarse filter to be considered candidate protected sites. Significant features identified include old-growth forests, wetlands, ravines, headwaters, lakeshores, coastlines, lagoons, talus slopes, forested floodplains, ephemeral rivers, oxbow lakes, riparian zones, and mountain barrens. Other studies have subdivided Nova Scotia into a series of 80 distinct natural landscape units, most of which have few or no protected areas. A Stora-owned system of nature reserves could help fill significant representation gaps within the province-wide system of protected areas, since nearly three-quarters of landscape units containing Stora properties are inadequately represented with existing protected sites. Other Stora-owned properties are located along significant waterways or positioned adjacent to larger existing protected areas. Later stages of this project will field-verify interpretations of the coarse filter analysis and further refine the list of candidate protected sites presented here.
\end{abstract}

En Nouvelle-Écosse, la société forestière Stora Port Hawkesbury Limited possède 280 propriétés dans I'île du Cap-Breton et dans l'est de la partie continentale; la superficie totale des propriétés est de 24590 ha. La présente étude utilise le principe du filtre brut pour établir quelles propriétés renferment des caractéristiques naturelles représentatives et exceptionnelles pour la création d'un réseau de réserves naturelles privées. On a utilisé des photographies aériennes pour documenter chaque propriété. Environ $35 \%$ des propriétés privées analysées ont été retenues pour analyse plus poussée. Parmi les éléments importants repérés, on compte des vieilles forêts, des milieux humides, des ravins, des eaux d'amont, des rivages de lacs, des côtes, des lagunes, des pentes d'éboulis, des plaines inondables boisées, des rivières éphémères, des méandres morts, des zones riveraines et des landes de montagnes. Dans d'autres études, on a subdivisé la Nouvelle-Écosse en 80 unités de paysage naturel, dont la plupart renferment peu de zones protégées ou aucune. Comme près des trois quarts des unités de paysage qui comprennent des propriétés de la Stora ne sont pas bien représentées dans les sites protégés actuels, un réseau de réserves naturelles appartenant à la société Stora pourrait contribuer à combler des lacunes importantes dans la représentation des types de milieux dans le réseau provincial de zones protégées. D'autres propriétés de cette société sont situées le long d'importantes voies navigables ou sont adjacentes à de grandes zones protégées. Dans les étapes ultérieures du présent projet, on validera sur le terrain les résultats de l'analyse par filtre brut et améliorera la liste des sites candidats présentés dans le présent document.

\section{Introduction}

It is difficult to establish a truly representative system of protected areas in Nova Scotia using public lands alone, since less than 30\% of the provincial landmass is owned by the Crown (see: Sutherland 1996, 1997). Even if all public lands were to be designated as protected, for instance, regions lacking sizable tracts of Crown land, such as the Annapolis Valley, the Bras d'Or Lake Plain, the Northumberland Strait area, or the Bridgewater drumlin field district, would still be without substantive areas of protected wilderness. Thus, in Nova Scotia, it is imperative to incorporate systems of 
privately-owned nature reserves into the existing system of publicly-owned protected sites, to properly address a conservation strategy for the province.

Two non-governmental organizations have been responsible for securing most protected private lands in Nova Scotia: (1) The Nova Scotia Nature Trust (NSNT 2002), and (2) the Nature Conservancy of Canada (NCC 2002). Since its establishment in 1994, the Nova Scotia Nature Trust has secured conservation easements and stewardship agreements at several sites throughout the province, and has acquired eight private properties for nature reserves (NSNT 2002). Particular attention has been focused on Hants County (Anonymous 1997, Sutherland 1998), the Cape Breton Highlands (Anonymous 2000), and the coastal plain flora areas of southwestern Nova Scotia (Sam 2000). The Nature Conservancy of Canada has acquired twenty properties in Nova Scotia since 1970, with a total cumulative area of 3000 ha (NCC 2002). Recent additions to their system include properties at Musquodoboit Harbour, Gaff Point, and Prospect High Head (NCC 2002). Most private reserves in Nova Scotia, however, have been established opportunistically, with few having been systematically selected to complement other conservation initiatives within the province. As a result, large gaps still exist within the provincial system of publicly-owned protected wilderness sites, threatening the long-term survival of many important ecosystems in large portions of the province.

Here, I examine the private land holdings of the largest forestry company operating in Nova Scotia, Stora Port Hawkesbury Limited, to determine which of its private properties maintain representative and outstanding natural phenomena of greatest importance for protection within a system of privately-owned nature reserves. This study marks the first serious attempt in the province to systematically incorporate properties from a single landowner into a privately-owned network of nature reserves. A standardized coarse filter analysis was used to assess the ecological importance of each private land holding. This technique focuses biological conservation at a macro scale level, and usually involves the protection of communities, ecosystems, habitats, and landscapes (Noss 1987, Hunter et al. 1988, Gauthier 1992, Scott et al. 1993, Noss \& Cooperrider 1994). For examples from Nova Scotia, refer to Leduc \& Smith (1992), Lynds \& Leduc (1995), and Beazley (1997). Research presented here represents the initial phase of a multi-stage hierarchical analysis that will culminate in the eventual protection of Stora's most ecologically significant private land holdings (Miller 1998).

\section{Objectives}

(1) To identify representative and outstanding natural features on the private land holdings of Stora Port Hawkesbury Limited.

(2) To create a list of candidate sites from which properties can eventually be selected as nature reserves.

\section{Study Area}

Stora Port Hawkesbury Limited is a subsidiary of Stora-Enso Limited, based in Sweden. It maintains cutting rights on approximately one third (620 923 ha) of Nova Scotia's Crown-owned property, including most public lands from Cape Breton Island and eastern mainland Nova Scotia. In addition to these public land holdings, the company also owns a number of private properties outright, scattered throughout this same general region (Fig. 1).

At the onset of this project, Stora Port Hawkesbury Limited maintained two hundred eighty privately owned properties on Cape Breton Island and eastern mainland Nova 


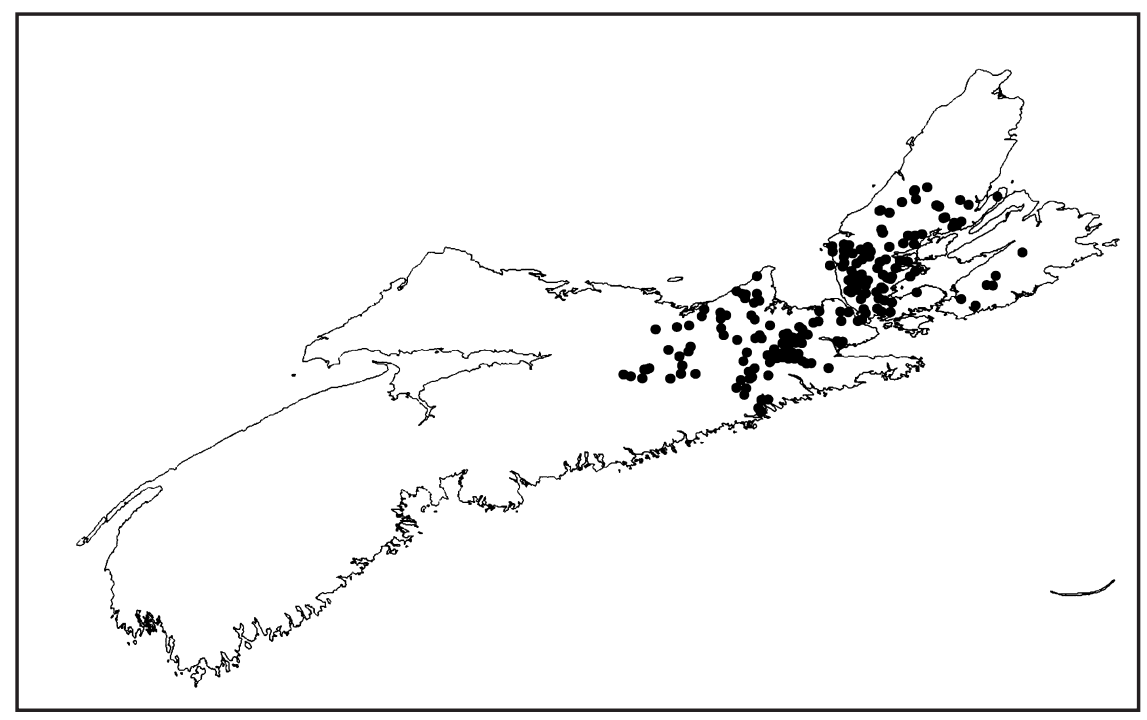

Fig 1 Private land holdings of Stora Port Hawkesbury Limited

Scotia, ranging in size from 0.4 ha to 819.9 ha, with a total cumulative area of 24590 ha. Since several of these private land holdings were positioned adjacent one another, the total number of distinct areas maintained by Stora at the time of this project was somewhat less than two hundred eighty, totaling one hundred eighty-six distinct land units. Ninety-five parcels were located on Cape Breton Island, forty-three in Antigonish County, twenty-four in Guysborough County, and twenty-four in Pictou County. Three additional properties in Cumberland and Colchester Counties, and one on Prince Edward Island, were not included in the present study.

\section{Methods}

The private land holdings of Stora Port Hawkesbury Limited were subdivided into three groups, including those from (1) Cape Breton Island, (2) Guysborough County, and (3) Pictou/Antigonish Counties. Properties from Cape Breton Island were labeled C1 through C95, those from Guysborough County from G1 to G24, and Pictou/ Antigonish Counties from P1 to P67. A labeled parcel of land consisted of either an individual Stora property or a conglomerate of adjacent properties. For detailed maps showing the locations of each private land holding refer to Miller (1998).

All private land holdings were analyzed solely from aerial photographs. This approach is comparable to other coarse filter analyses that have been carried out in Nova Scotia (e.g. DNR 1994a, Leduc \& Smith 1992, Lynds \& Leduc 1995). Stora properties in Guysborough, Pictou, and Antigonish Counties were assessed using 1997 aerial photographs, while those from Cape Breton Island were assessed using 1993 aerial photographs. These were the most recent aerial photographs available for these areas at the time of this analysis. Aerial photographs were unavailable for eighteen of the one hundred eighty-six Stora land holdings, leaving these properties unassessed at the conclusion of the coarse filter analysis. A supplemental review still needs to be 
carried out, therefore, to determine which of these properties possess natural features of importance to a Stora-owned system of nature reserves.

The coarse filter analysis used for this project involved two standard approaches to the selection of protected areas. The first assessed the representation potential of the Stora-owned properties, while the second examined outstanding natural phenomena. Additional significance was attached to properties located along important waterways or positioned adjacent to existing protected wilderness sites. Any land holding found to possess important features, either for representivity or outstanding natural phenomena, was considered a candidate protected site.

\section{Representation}

A representative approach to the design of a system of protected areas seeks to establish reserves in all landscape divisions of a given region so that a full spectrum of biodiversity and ecosystem-types can be protected (e.g. Margules et al. 1988, Bedward et al. 1992, Noss \& Cooperider 1994, Beazley 1997, Primack 1998). Two primary land classification systems were in place for Nova Scotia at the time of this study: (1) an eighty landscape scheme developed by the Parks and Recreation Division of the Department of Natural Resources (DNR 1994a, 1997), and (2) an eight ecoregion partition developed by Environment Canada (Environment Canada 1995). The private land holdings of Stora Port Hawkesbury Limited were assessed using the eighty landscape scheme, as it was the most detailed biogeographical description of the province available at the time. It also better enabled the Stora-owned properties to be placed in a provincial representation context, as the publicly-owned system of protected wilderness areas in Nova Scotia was developed using the eighty landscape scheme and representation levels had already been predetermined for each of its landscape units (DNR 1994a, Lynds \& Leduc 1995).

Land holdings identified from the aerial photographs as maintaining ecosystems characteristic of an underrepresented landscape were flagged as potential candidate protected sites. Representivity was determined by comparing landforms and forest-types identified from the aerial photographs with those expected from published summary descriptions of each natural landscape-type (DNR 1997). Properties with intact ecosystems, but occurring in landscapes already satisfactorily represented with protected areas, were typically rejected as candidate nature reserves unless they also maintained features of outstanding natural value or other attributes important for inclusion within a system of protected areas.

\section{Outstanding features}

In addition to representivity, the private land holdings of Stora Port Hawkesbury Limited were also assessed for the presence of outstanding natural features. Table 1 lists the outstanding landscape elements that were actively searched for on the aerial photographs. All are identifiable at the 1:10 000 scale of the aerial photographs. This list was compiled, in part, from suggestions by staff members of the Protected Areas Division of the Nova Scotia Department of Environment and Labour. Additional outstanding natural features not included on this list were also considered if they were observed on the aerial photographs. These results were later supplemented with published information on geologic formations, significant wetlands, old forests, and rare species (e.g. DME 1979, Lynds 1992, Stora 1994). 
Table 1 List of outstanding natural features actively searched for on the aerial photographs of Stora-owned properties.

\begin{tabular}{ll}
\hline Outstanding natural features & \\
\hline Mountain coves & Lake islands \\
Mountain barrens & Ephemeral ponds \\
Talus slopes & Old forests \\
Salt marshes & Cliffs \\
Tidal flats & Coastal islands \\
Bogs & Coastal barrens \\
Fens & Coastal ledges \\
Freshwater marshes & Beaches \\
Swamps & Dunefields \\
Estuaries & Uncommon forest-types \\
Lagoons & Inland barrens \\
Eel grass beds & Riparian zones \\
\hline
\end{tabular}

\section{Results and discussion}

Sixty-eight of the one hundred eighty-six Stora land holdings were found to contain representative or outstanding natural features of some significance to conservation and were subsequently caught by the coarse filter (Fig. 2). Twenty of these properties exhibited no evidence of recent forest harvesting. The other forty-eight had been modestly logged in some areas, but maintained important and intact ecological features elsewhere. The one hundred three land holdings that did not pass through the coarse filter analysis were largely clearcut, extensively roaded, or had been partially converted to conifer plantations.

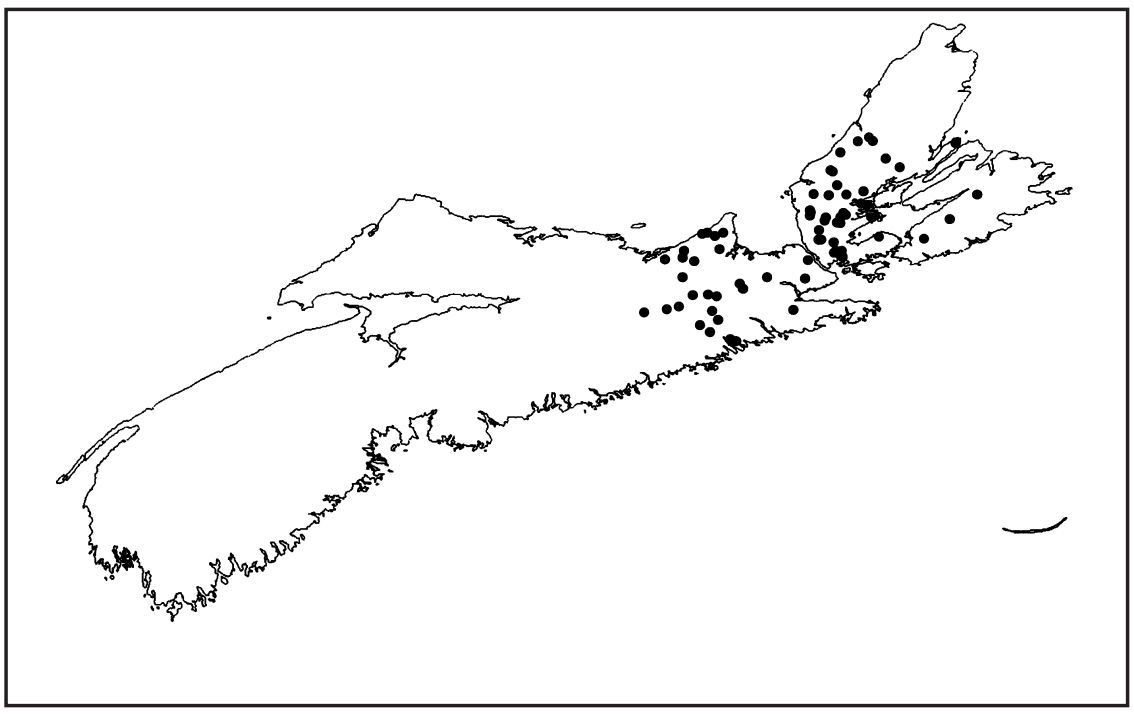

Fig 2 Stora-owned properties that were selected by the coarse filter analysis for possessing representative or outstanding natural features. 
Table 2 Landscapes containing Stora-owned properties and their current representation status.

\begin{tabular}{|c|c|c|}
\hline Landscape (\#) & Landscape title & Representation* \\
\hline 22 & Northumberland Strait Plain & inadequate \\
\hline 26 & Central Rolling Hills & inadequate \\
\hline 35 & Eastern Shore Quartzite Plains & partial \\
\hline 38 & Guysborough Headlands & inadequate \\
\hline 39 & Canso Granite Barrens & satisfactory \\
\hline 40 & Aspen Drumlin Plain & inadequate \\
\hline 41 & St. Mary's Plain & partial \\
\hline 42 & Pictou River Hills & inadequate \\
\hline 43 & McArras Brook Dissected Coast & inadequate \\
\hline $44 \mathrm{a}$ & Pictou-Antigonish Hills (Pictou) & inadequate \\
\hline $44 b$ & Pictou-Antigonish Hills (Antigonish) & inadequate \\
\hline 45 & South River Low Hills & inadequate \\
\hline 46 & Mulgrave Hills & satisfactory \\
\hline 48 & Bras d'Or Lake Plain & inadequate \\
\hline 49 & North Mountain Ridge & partial \\
\hline $50 a$ & Bras d'Or Fault Ridges (Sporting Mountain) & inadequate \\
\hline $50 b$ & Bras d'Or Fault Ridges (East Bay Hills) & inadequate \\
\hline 51 & Forchu Hill Cliffs and Beaches & satisfactory \\
\hline 52 & Barren Hill Drumlins & inadequate \\
\hline 54 & Mira River Hills and Ridges & inadequate \\
\hline 56 & Sydney Plain & inadequate \\
\hline 58 & Skye River Hills and Valleys & inadequate \\
\hline 59 & Judique Plain and Hills & inadequate \\
\hline 61 & Western Cape Breton Coastal Plain (Inverness) & inadequate \\
\hline 62 & Masons Mountain & inadequate \\
\hline 63 & Keppock Mountain & satisfactory \\
\hline $64 a$ & Cape Breton Boreal Plateau (Gillanders Mountain) & inadequate \\
\hline $64 b$ & Cape Breton Boreal Plateau (Central) & satisfactory \\
\hline 65 & Margaree-Middle River Valleys & inadequate \\
\hline 68 & Interior Steep Slopes & satisfactory \\
\hline 69 & Central Cape Breton Hills & inadequate \\
\hline 70 & Kelly's Mountain & inadequate \\
\hline
\end{tabular}

* Source: (DNR 1994a)

\section{Representation}

Stora-owned properties are located within twenty-nine of Nova Scotia's eighty natural landscapes (Table 2). Since three of these landscapes contain sub-units, in total, thirty-two distinct biogeographical land units were assessed by the coarse filter analysis. Most Stora-owned properties are located within landscapes currently underrepresented with publicly-owned protected areas (Table 3). Of the thirty-two distinct land units containing Stora properties, for instance, six were satisfactorily represented $(19 \%)$, none near-satisfactorily represented $(0 \%)$, three partially-represented (9\%), and twenty-three inadequately represented (72\%) (Fig. 3). Thus, a Stora-owned system of nature reserves is well positioned to fill representation gaps existing within the publicly-owned system of protected wilderness sites, since most of its candidate reserves occur within inadequately represented landscapes.

Several underrepresented landscapes, in particular, could benefit from the implementation of a Stora-owned system of nature reserves (Fig. 4, Table 4). The inadequately represented Bras d'Or Lake Plain (\#48), Skye River (\#58), and Judique 
Table 3 Stora-owned properties per landscape.

\begin{tabular}{|c|c|c|}
\hline Landscape (\#) & Stora properties & Representation* \\
\hline 22 & P15, P16, P17, P18, P19 & inadequate \\
\hline 26 & P1 & inadequate \\
\hline 35 & G1, G3, G10, G11, G14 & partial \\
\hline 38 & G11, G12, G13 & inadequate \\
\hline 39 & G14 & satisfactory \\
\hline 40 & G2, G4, G6 & inadequate \\
\hline 41 & P2, P3, P4, P5, G1, G2, G5 & partial \\
\hline 42 & P6, P7, P16 & inadequate \\
\hline 43 & P60, P63, P64 & inadequate \\
\hline $44 a$ & $\begin{array}{l}\text { P8, P9, P10, P11, P12, P13, P14, P20, P21, P22, } \\
\text { P23, P24, P62, P63, P65, P66, P67 }\end{array}$ & inadequate \\
\hline 44b & P55, P56, P57 & inadequate \\
\hline 45 & $\begin{array}{l}\text { P25, P26, P27, P28, P30, P31, P32, P33, P34, } \\
\text { P35, P36, P37, P38, P39, P40, P41, P42, P43, P44, } \\
\text { P45, P46, P47, P48, P49, P50, P51, P52, P53, P54, } \\
\text { P58, P59, P61, G8, G19 }\end{array}$ & inadequate \\
\hline 46 & $\begin{array}{l}\text { P29, G6, G9, G15, G16, G17, G18, G19, G20, } \\
\text { G21, G22, G23, G24 }\end{array}$ & satisfactory \\
\hline 48 & $\begin{array}{l}\text { C8, C9, C10, C11, C12, C13, C14, C15, C16, } \\
\text { C17, C18, C20, } \\
\text { C21, C22, C23, C42, C43, C44, C45, C46, C47, } \\
\text { C48, C49, C50, C51, C52, C55, C56 }\end{array}$ & inadequate \\
\hline 49 & C53, C54 & partial \\
\hline 50a & $\mathrm{C} 7, \mathrm{C} 8$ & inadequate \\
\hline 50b & $\mathrm{C} 2, \mathrm{C} 3, \mathrm{C} 4$ & inadequate \\
\hline 51 & C5 & satisfactory \\
\hline 52 & C5, C6 & inadequate \\
\hline 54 & C1 & inadequate \\
\hline 56 & C1 & inadequate \\
\hline 58 & $\begin{array}{l}\text { C19, C23, C24, C25, C26, C27, C40, C41, C42, } \\
\text { C62, C63, C70, C71, C74, C75, C76, C77 }\end{array}$ & inadequate \\
\hline 59 & $\begin{array}{l}\text { C19, C24, C25, C26, C27, C28, C29, C30, C31, } \\
\text { C32, C33, C34, C35, C36, C37, C38, C39, C40, } \\
\text { C41, C61, C64, C65, C66, C67, C68, C69, C70, } \\
\text { C71, C72, C73 }\end{array}$ & inadequate \\
\hline 61 & C77 & inadequate \\
\hline 62 & C78, C79, C80 & inadequate \\
\hline 63 & C57, C58, C59, C60, C61, C81, C82, C83, C85 & satisfactory \\
\hline $64 a$ & C83 & inadequate \\
\hline $64 b$ & C86, C87, C88, C92, C93, C94 & satisfactory \\
\hline 65 & C80, C81, C82, C84, C85, C86 & inadequate \\
\hline 68 & C86, C87, C88, C94 & satisfactory \\
\hline 69 & С87, С88, С89, С90, С91, С92, С94 & inadequate \\
\hline 70 & C95 & inadequate \\
\hline
\end{tabular}

*Source: (DNR 1994a)

Plain natural landscapes (\#59), for example, each contain over a dozen land holdings identified by the coarse filter analysis as maintaining ecologically significant features. Likewise, the inadequately represented landscapes of Pictou-Antigonish Hills (Pictou subdivision) (\#44a) and South River Low Hills (\#45) also contain several important properties identified by the coarse filter analysis. Thus, the implementation of a Stora- 


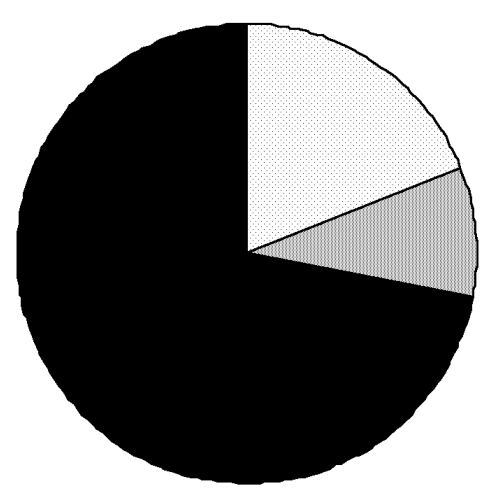

satisfactory

will partial

inadequate

Fig 3 Protected area representation for landscapes containing Stora-owned properties; $72 \%$ inadequately represented; $9 \%$ partially represented; $0 \%$ near satisfactorily represented; $19 \%$ satisfactorily represented.

owned system of nature reserves could help advance representational targets in Nova Scotia for several key landscapes currently underrepresented with publicly-owned protected sites.

Properties C80 and C95 are particularly important to a Stora-owned system of nature reserves, since these land holdings occur within two of the smallest underrepresented landscapes in Nova Scotia: Masons Mountain (\#62) and Kelly's Mountain (\#70). Because these landscapes are so small, approximately 8500 ha and 11500 ha respectively (DNR 1997), the designation of properties C80 and C95 as nature reserves could unilaterally advance representation targets within these two landscapes. In the case of Kelly's Mountain, for instance, property C95 (819.9 ha) accounts for approximately $7 \%$ of the entire landscape. Its protection would fill an important gap within the existing system of protected wilderness sites within the province.

\section{Outstanding Features}

Fifty-nine of the one hundred eighty-six Stora-owned parcels of land were identified as containing one or more outstanding natural features (Table 5). Thirty-nine are located on Cape Breton Island, ten in Guysborough County, six in Antigonish County, and four in Pictou County. Outstanding natural features identified by the coarse filter analysis include old-growth forest, old forest, climax forest, significant wetlands, significant floodplains, talus slopes, ravines, headwaters, lakeshores, lake islands, lagoons, ephemeral rivers, oxbow lakes, coastal zones, tidal areas, limestone regions, and mountain barrens. In addition to these features, literature reviews also flagged sixteen properties as potentially containing rare or threatened species.

Given the scarcity of old-growth forests in Nova Scotia (e.g. Lynds 1992, DNR 1994b), all forty-one Stora-owned properties found to possess old forest systems were considered ecologically important. A number of different forest types were identified, including a combination of deciduous, coniferous, and mixed forest stands. Most properties containing old growth forest were found to occur on Cape Breton Island. This may be an artifact of the aerial photograph analysis, since these properties were examined using older photographs than those used for properties on mainland Nova 
Table 4 Stora-owned properties per landscape that were selected by the coarse filter analysis as candidate protected sites.

\begin{tabular}{|c|c|c|}
\hline Landscape(\#) & Stora properties & Representation* \\
\hline 22 & P16 & inadequate \\
\hline 26 & P1 & inadequate \\
\hline 35 & G1, G3, G10, G11, G14 & partial \\
\hline 38 & G11, G12, G13 & inadequate \\
\hline 39 & G14 & satisfactory \\
\hline 40 & G2, G4 & inadequate \\
\hline 41 & G1, G2, G5 & partial \\
\hline 42 & P16 & inadequate \\
\hline 43 & P63, P64 & inadequate \\
\hline $44 a$ & P8, P9, P20, P24, P63, P65, P66, P67 & inadequate \\
\hline $44 \mathrm{~b}$ & P55 & inadequate \\
\hline 45 & P28, P30, P58, P59, P61, G19 & inadequate \\
\hline 46 & P29, G15, G19, G22, G23 & satisfactory \\
\hline 48 & $\begin{array}{l}\text { C10, C11, C12, C14, C21, C22, C23, C43, C45, } \\
\text { C46, C47, C48, C50, C55, C56 }\end{array}$ & inadequate \\
\hline 49 & C54 & partial \\
\hline $50 a$ & C7 & inadequate \\
\hline $50 \mathrm{~b}$ & $\mathrm{C} 3, \mathrm{C} 4$ & inadequate \\
\hline 51 & C5 & satisfactory \\
\hline 52 & C5, C6 & inadequate \\
\hline 54 & C1 & inadequate \\
\hline 56 & $\mathrm{C} 1$ & inadequate \\
\hline 58 & $\begin{array}{l}\text { C19, C23, C24, C25, C26, C40, C41, C62, C63, } \\
\text { C70, C74, C75, C76, C77 }\end{array}$ & inadequate \\
\hline 59 & $\begin{array}{l}\text { C19, C24, C25, C26, C34, C39, C40, C41, C65, } \\
\text { C66, C67, C68, C69, C70, }\end{array}$ & inadequate \\
\hline 61 & C77 & inadequate \\
\hline 62 & $\mathrm{C} 80$ & inadequate \\
\hline 63 & C57, C58, C59, C60, C82, C83 & satisfactory \\
\hline $64 a$ & C83 & inadequate \\
\hline $64 \mathrm{~b}$ & C86, C88, C94 & satisfactory \\
\hline 65 & C80, C82, C86 & inadequate \\
\hline 68 & C86, C88, C94 & satisfactory \\
\hline 69 & C88, C94 & inadequate \\
\hline 70 & C95 & inadequate \\
\hline
\end{tabular}

* Source: (DNR 1994a)

Scotia. Later stages of this project may reveal that several of these sites may no longer exist in an old growth forest condition and the reserve system will have to be adjusted accordingly.

Several of Stora's properties were found to contain important wetland systems, including examples of bogs, fens, riparian zones, and shallow open-water areas. In addition to the important habitat that these systems provide, wetlands also perform a number of crucial ecological services, including water purification, groundwater regulation, temperature modification, and sedimentation control, among others (e.g. Mitsch \& Gosselink 2000). The most significant wetlands identified by this analysis were found on properties C14, C55, C56, and G11.

Properties located along the St. Mary's River in Guysborough and Pictou Counties, and the River Denys south of the Bras d'Or Lakes on Cape Breton Island, were assigned 


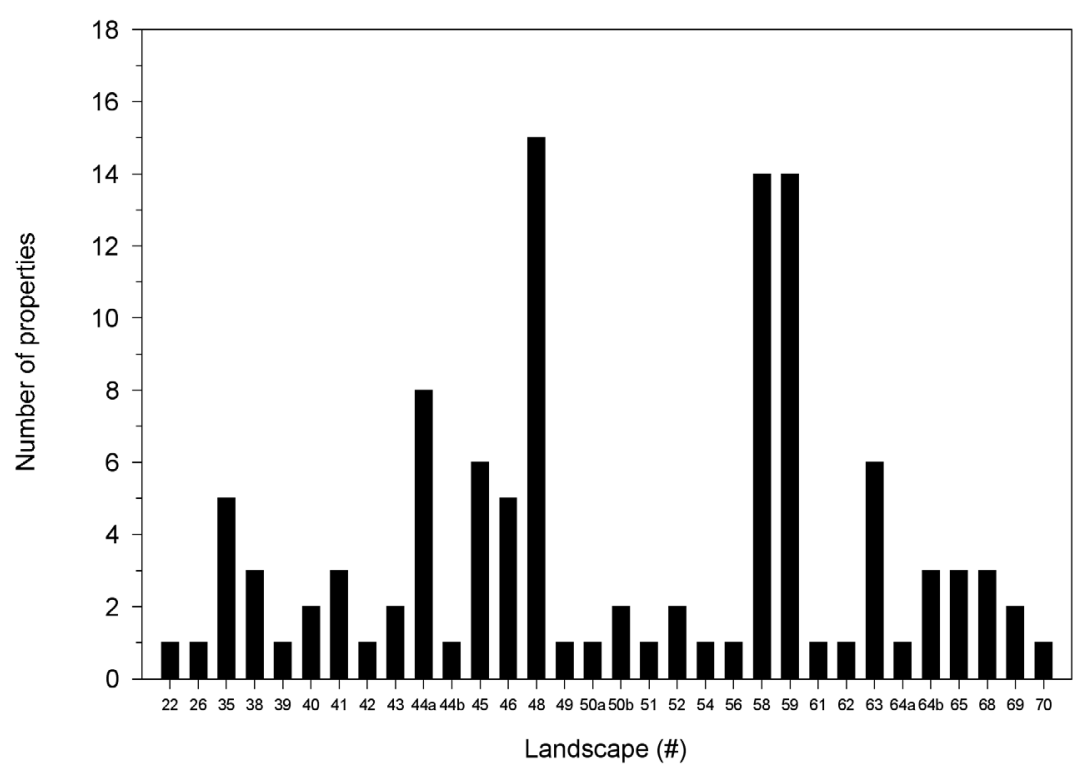

Fig 4 Stora-owned properties per landscape that were selected by the coarse filter analysis. Landscape numbers refer to titles presented in Table 2.

a high level of conservation importance given the ecological significance of these waterways. The St. Mary's River contains one of the highest concentrations of wood turtles (Clemmys insculpta) in the province, a species classified by the Committee On the Status of Endangered Wildlife in Canada as being of special concern for conservation (COSEWIC 2001). The rare eastern pearlshell (Margaritifera margaritifera) and brook floater (Alasmidonta varicosa) freshwater mussels also occupy the river, and its riverbanks maintain patches of old-growth forest and important intervale habitat. Likewise, the River Denys is significant for its forested floodplains, rare intervale flora, karst topography, and for a small breeding population of wood turtles. Properties G1, G3, G5, and P8 maintain shoreline frontage on the St. Mary's River, while C45, C46, and C47 occur along the River Denys.

Likewise, properties located along the shores of the Bras d'Or Lakes on Cape Breton Island were also assigned a high level of conservation importance. This $260 \mathrm{~km}^{2}$ brackish water body, sometimes referred to as an inland sea or estuary, is naturally connected to the ocean via two restricted channels and one man-made canal system (Davis \& Browne 1996, Petrie \& Raymond 2002, Shaw et al. 2002). It maintains a rich diversity of coastal barriers (Taylor \& Shaw 2002), as well as several ecologically significant and disjunct estuarine communities (Davis \& Browne 1996, Lambert 2002). Properties C55 and C56 were found to possess shoreline frontage on the Bras d'Or Lakes. They maintain a number of important natural features of importance for protection, including beaches, lagoons, lake islands, significant wetlands, and old forest.

\section{Adjacent protected areas}

Large protected areas are better able to support minimum viable populations, perpetuate large-scale natural disturbance regimes, and facilitate long-term changes in 
Table 5 Stora-owned properties found to maintain outstanding natural features.

\begin{tabular}{ll}
\hline Outstanding feature & Properties \\
\hline old forest & C10, C11, C12, C19, C21, C25, C26, C34, C39, C40, \\
& C41, C43, C45, C48, C54, C55, C56, C57, C62, C65, \\
& C66, C67, C68, C70, C76, C80, C82, C83, C86, C95, \\
& G2, G3, G4, G23, P1, P12, P61, P63, P64, P65, P67 \\
significant wetland & C14, C55, C65, C95, G11 \\
significant floodplain & C3, C14, C21, C22, C46, C47, C61, G1, G3, \\
& G5, P8, P30, P55, P61 \\
talus slope & C95 \\
ravine & C66, P61, P65 \\
headwater area & C76, C95 \\
lake shoreline & C55, C56, G23 \\
lake island & C55, G23 \\
lagoon & C55, C56 \\
beach & C55, C56 \\
ephemeral river & C14 \\
oxbow lake & C14 \\
coastal frontage & C95 \\
tidal influence & C14, C95 \\
frontage on significant waterway & C45, C46, C47, G1, G3, G5, P8 \\
frontage on the Bras d'Or Lake & C55, C56 \\
limestone area & C21, C22, C45, C46, C47, C48, C50, C54, \\
mountain barren & C56, C75, C76 \\
rare species habitat & C95 \\
& C14, C19, C21, C22, C45, C46, C47, C74, C95, \\
\hline
\end{tabular}

the natural environment due to climate change than are small protected areas (e.g. Diamond 1975, IUCN 1980, Peters \& Darling 1985, Newmark 1987, 1995, Grumbine 1990, Noss 1991, Baker 1992, Caughley \& Gunn 1996, Beazley 1997, Meffe \& Carroll 1997). In Nova Scotia, however, most publicly-owned reserves are widely scattered and relatively small by comparison with the norm in Canada. Only two areas of the province have protected areas exceeding 100000 ha of concatenated protected space. These are (1) Kejimkujik National Park/ Tobeatic Wilderness Area, and (2) Cape Breton Highlands National Park/ Pollets Cove - Aspy Fault Wilderness Area. Thus, Stora-owned properties located adjacent to, or near, existing protected areas were considered important inclusions for a nature reserve system because they could effectively expand the size of existing core reserves.

Property G15 is positioned adjacent the 5720 ha Ogden Round Lake Wilderness Area in Guysborough County, while property C86 is adjacent the 5471 ha Middle River Wilderness Area in the Cape Breton Highlands. Properties C39, C40, and C41 are located near the Bornish Hills Ecological Reserve; C58, C59, and C60 near Trout Brook Wilderness Area; C88 near Middle River Wilderness Area; C94 near North River Wilderness Area; G14 near the Bonnet Lake Barrens Wilderness Area; and G3 near both the Big Bog Wilderness Area and the Melrose International Biological Programme (IBP) site.

\section{Ecologically significant properties}

Several properties examined by this analysis possess more than one significant feature of importance to a Stora-owned system of nature reserves, including both representative and outstanding natural phenomena. Six of these properties, in 


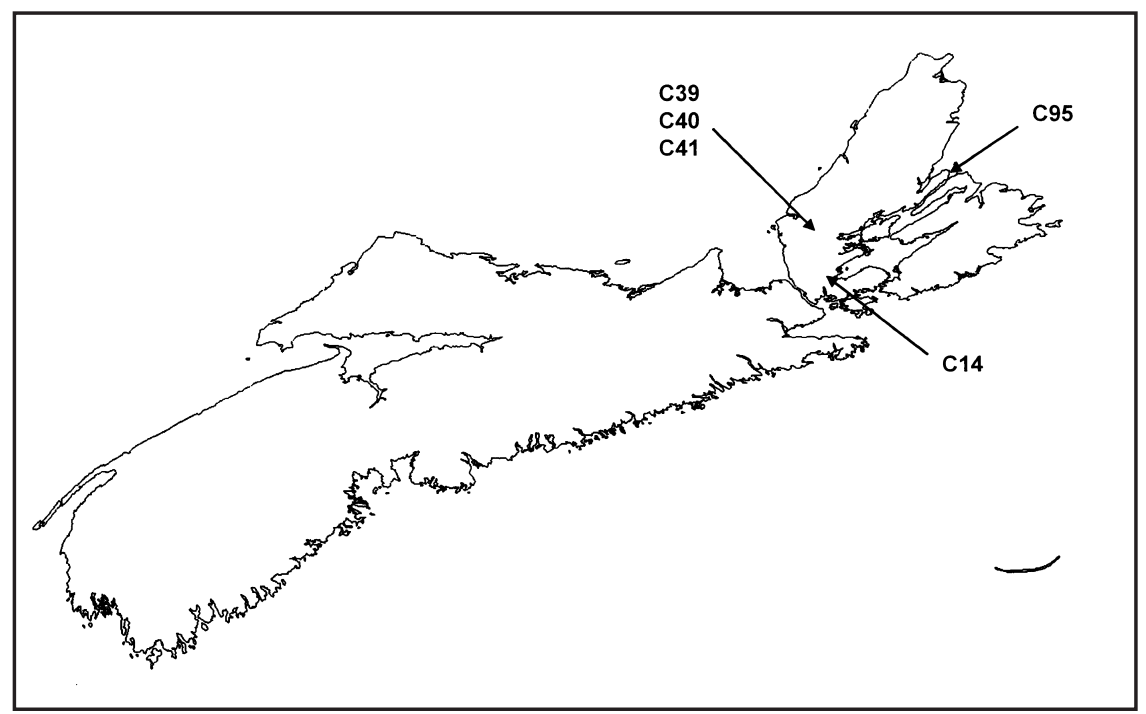

Fig 5 Locations of specified Stora land holdings.

particular, are of greatest importance for protection, including properties $\mathrm{C} 14$ and C95 individually, and properties C39, C40, and C41 together as a conglomerate (Fig. 5). These land holdings are described below.

Property C14 Located midway between Port Hawkesbury and the southern extremity of the Bras d'Or Lakes, property $\mathrm{C} 14$ contains one of the largest remaining undisturbed floodplains in Nova Scotia. This 680 ha property is characterized by a wetland - dwarf spruce complex with several examples of ephemeral rivers, oxbow lakes, small lichen-dominated barrens, and several rare taxa. It is also significant for its representation potential, as it occurs within the inadequately represented landscape of the Bras d'Or Lake Plain.

Property C95 The largest land holding assessed by this analysis was property C95. It is 819.9 ha in size and covers much of the northeastern side of Kluscap Mountain, otherwise known as Kelly's Mountain. This land holding registered the highest number of outstanding natural features on a Stora-owned property, including features such as old-growth hardwood forest, old-growth mixed forest, old-growth hemlock forest, wetland complexes, coastal frontage, mountain barrens, talus slopes, exceptional geologic features, and a diverse habitat mosaic characteristic of the Kelly's Mountain natural landscape. The entire mountain is also sacred to the Mi'qmak people as the birthplace of Kluscap and traditional native ceremonies are sometimes performed nearby, at the entrance to the Fairy Hole Cave at Cape Dauphin. Property C95 is also well positioned to fill a gap within the relatively small, but inadequately represented landscape of Kelly's Mountain. Since Crown lands adjacent to property C95 are also under consideration for protected status (DNR 1996), this land holding has the added potential of becoming a constituent of a nature reserve conglomerate.

Properties C39, C40, and C41 The closely positioned land holdings of C39, C40, and C41 are located within the inadequately represented Skye River and Judique Plain natural landscapes. These properties, together as a cluster, maintain a total cumulative area of 1185 ha, nearly $5 \%$ of the total area of all privately-owned Stora land holdings. Together, they possess a representative expanse of old-growth Acadian hardwood 
forest continuous with the nearby, publicly-owned Bornish Hills Ecological Reserve. This makes the concept of connectivity (e.g. Soulé \& Simberloff 1986, Simberloff \& Cox 1987, Hudson 1991, Noss \& Cooperrider 1994, Caughley \& Gunn 1996, Primack 1998, Beazley et al. 2004) particularly relevant for properties C39, C40, and C41, since these land holdings could be interconnected with wilderness corridors that extend to include the Bornish Hills Ecological Reserve. This would help establish a relatively large protected area within a region of the province severely fragmented with clearcuts and logging roads.

\section{Future work: fine filter analysis}

The coarse filter analysis presented in this paper identified sixty-eight of the one hundred eighty-six Stora land holdings as areas from which protected areas can eventually be selected. Later stages of the project will further reduce this number to ensure that the most significant Stora-owned properties are the ones actually chosen for protection. This could be achieved using a fine filter analysis (see: Noss 1987, Hunter et al. 1988, Noss \& Cooperrider 1994), which would involve field-verifying the results of the coarse filter analysis presented here, and collecting site specific baseline data on features such as topography, bedrock geology, geomorphology, habitat-types, stand structures, and species compositions, among others. Land holdings still found to maintain important representative or outstanding natural features would then be designated as nature reserves.

To prioritize reserve designations, properties could be scored quantitatively using a set ranking procedure (see: Noss 1993, DNR 1994a). This may involve scoring properties for a variety of phenomena, including representation, outstanding natural features, wilderness value, and rare species, among others. These categories could also be differentially weighted to give preferences to Stora-owned properties with specific natural features best addressing the conservation objectives of the fine filter analysis. Properties receiving the highest scores would then be considered the highest priority for protection.

In order to prevent the degradation of candidate protected sites between their initial coarse filter identification and such time as they can be formally established as nature reserves, interim protection should be afforded those sites deemed most ecologically significant. Quickening the pace of reserve designations would also limit the risk of degradation by shortening the time period in which candidate protected areas remain in an interim state.

\section{Conclusions}

Sixty-eight of the one hundred eight-six Stora land parcels examined by this analysis were found to maintain sufficient representational features or outstanding natural phenomena to be considered candidate reserves for the establishment of a protected area system. Since most of these properties occur within landscapes that are inadequately represented with existing protected sites, a Stora-owned system of nature reserves is well positioned to help fill significant representational gaps in the provincial network of publicly-owned protected wilderness areas. Several of the examined properties were also found to maintain outstanding ecological features of provincial significance, including one of the largest undisturbed floodplains in Nova Scotia, several assemblages of intact old-growth Acadian forest, and important habitat for rare or threatened species. Others were located along significant waterways or positioned adjacent to existing protected wilderness areas. 


\section{Acknowledgements}

Stora Port Hawkesbury Limited provided funding for this research. Thanks to Bevan Lock and Bonnie Sutherland for getting this project off the ground, and to David Mackinnon, John Leduc, and Art Lynds of the Protected Areas Division of the Department of the Environment for their valuable suggestions. Thanks also to the two anonymous readers of this manuscript whose revisions were very much appreciated and helpful.

\section{References}

Anonymous (1997) Hants County conservation project receives funding. Nat Landsc: the newsletter of the Nova Scotia Nature Trust 3

Anonymous (2000) Land conservation campaign unveiled. Nat Landsc: the newsletter of the Nova Scotia Nature Trust 6

Baker WL (1992) The landscape ecology of large disturbances in the design and management of nature reserves. Landsc Ecol 7:181-194

Beazley K (1997) Ecological considerations for protected area system design. Proc NS Inst Sci 41:59-76

Beazley K, Willison JHM, Long R, MacKay P (2004) A report on a conservation planning process for a terrestrial and marine biodiversity conservation vision in Nova Scotia. Proc NS Inst Sci 42:359-373

Bedward M, Pressey RL, Keith DA (1992) A new approach for selecting fully representative reserve networks: addressing efficiency, reserve design and land suitability with an iterative analysis. Biol Conserv 62:115-125

Caughley G, Gunn A (1996) Conservation biology in theory and practice. Blackwell Science, Cambridge, MA

COSEWIC (Committee On the Status of Endangered Wildlife in Canada) (2001) Canadian species at risk, November 2001. COSEWIC, Canadian Wildlife Service, Environment Canada, Ottawa

Davis DS, Browne S (eds) (1996) The natural history of Nova Scotia: theme regions. Nimbus Publishing and the Province of Nova Scotia, Halifax

DME (Department of Mines and Energy) (1979) Geological map of Nova Scotia. Map at 1:2,000,000 scale. Nova Scotia DME, Halifax

DNR (Department of Natural Resources) (1994a) A proposed system plan for parks and protected areas in Nova Scotia. Nova Scotia DNR, Belmont, NS

DNR (1994b) An old forest strategy for Nova Scotia. Nova Scotia DNR, Halifax

DNR (1996) Kluscap (Kelly's) Mountain study area: evaluation of protection-orientated values. Parks and Recreation Division, Nova Scotia DNR, Halifax

DNR (1997) Natural landscapes of Nova Scotia: summary descriptions. Parks and Recreation Division, Nova Scotia DNR, Belmont, NS

Diamond JM (1975) The island dilemma: lessons of modern biogeographic studies for the design of nature reserves. Biol Conserv 7:129-146

Environment Canada (1995) Terrestrial ecozones and ecoregions of Canada. Map at 1:7500000 scale, Ottawa

Gauthier D (1992) Canadian Council on Ecological Areas framework for developing a nation-wide system of ecological areas: a strategy. Canadian Council on Ecological Areas (CCEA), Occasional paper 12, Ottawa

Grumbine RE (1990) Viable populations, reserve size, and federal lands management: a critique. Conserv Biol 4:127-134 
Hudson WE (ed) (1991) Landscape linkages and biodiversity. Defenders of Wildlife and Island Press, Washington, DC

Hunter ML Jr, Jacobson GL Jr, Webb T (1988) Paleoecology and the coarse-filter approach to maintaining biological diversity. Conserv Biol 2:375-385

IUCN (International Union for the Conservation of Nature and Natural Resources) (1980) World conservation strategy, Gland, Switzerland

Lambert TC (2002) Overview of the ecology of the Bras d'Or Lakes with emphasis on the fish. Proc NS Inst Sci 42:65-99

Leduc JM, Smith AD (1992) System planning for protection orientated provincial parks in Nova Scotia. In: Willison JHM, Bondrup-Nielsen S, Drysdale C, Herman TB, Munro NWP, Pollock TL (eds) Science and the management of protected areas. Elsevier, New York, p 139-144

Lynds A (1992) Provisional ecological characteristics of old-growth forests for Nova Scotia: an Acadian forest perspective. In: Willison JHM, Bondrup-Nielsen S, Drysdale C, Herman TB, Munro NWP, Pollock TL (eds) Science and the management of protected areas. Elsevier, New York, p 339-344

Lynds JA, Leduc JM (1995) Planning for the protection of biodiversity at the landscape level in Nova Scotia. In: Herman TB, Bondrup-Nielsen S, Willison JHM, Munro NWP (eds) Ecosystem monitoring and protected areas. Science and the Management of Protected Areas Association, Wolfville, NS, p 548-558

Margules CR, Nicholls AO, Pressey RL (1988) Selecting networks of reserves to maximise biological diversity. Biol Conserv 43:63-76

Meffe GK, Carroll CR (1997) Principles of conservation biology: second edition. Sinauer Associates, Sunderland, MA

Miller CA (1998) Ecological landscape analysis of private land holdings for Stora Port Hawkesbury Limited: recommendations for a system of protected areas. Contract document for Stora Port Hawkesbury Limited and the Nova Scotia NatureTrust, Halifax

Mitsch WJ, Gosselink JG (2000) Wetlands: third edition. John Wiley \& Sons, New York

NCC (Nature Conservancy of Canada) (2002) http://www.natureconservancy.ca

Newmark WD (1987) A land-bridge island perspective on mammalian extinctions in western North American parks. Nature (London) 325:430-432

Newmark WD (1995) Extinction of mammal populations in western North American national parks. Conserv Biol 9:512-526

Noss RF (1987) From plant communities to landscapes in conservation inventories: a look at the Nature Conservancy (USA). Biol Conserv 41:11-37

Noss RF (1991) Sustainability and wilderness. Conserv Biol 5:120-121

Noss RF (1993) A conservation plan for the Oregon coast range: some preliminary suggestions. Nat Areas J 13:276-290

Noss RF, Cooperrider AY (1994) Saving nature's legacy: protecting and restoring biodiversity. Defenders of Wildlife and Island Press, Washington, DC

NSNT (Nova Scotia Nature Trust) (2002) http://www.nsnt.ca

Peters RL, Darling JDS (1985) The greenhouse effect and nature reserves. Bioscience 35:707-717

Petrie B, Raymond J (2002) The oceanography of the Bras d'Or Lakes: general introduction. Proc NS Inst Sci 42:1-8

Primack RB (1998) Essentials of conservation biology: second edition. Sinauer Associates, Sunderland, MA

Sam D (2000) Nature Trust expands its coastal plain plant monitoring program. Nat Landsc: the newsletter of the Nova Scotia Nature Trust 6 
Scott JM, Davis F, Csuti B, Noss R and 8 others (1993) Gap analysis: a geographic approach to the protection of biological diversity. Wildl Monogr 123:1-41

Shaw J, Piper DJW, Taylor RB (2002) The geology of the Bras d'Or Lakes, Nova Scotia. Proc NS Inst Sci 42:127-147

Simberloff D, Cox J (1987) Consequences and costs of conservation corridors. Conserv Biol 1:63-71

Soulé ME, Simberloff D (1986) What do genetics and ecology tell us about the design of nature reserves? Biol Conserv 35:19-40

Stora Port Hawkesbury Limited (1994) Stora forest industries wetlands: inventory and management recommendations. Contract document for Stora Port Hawkesbury Limited, Port Hawkesbury, NS

Sutherland B (1996) Enhancing nature conservation on private land in Nova Scotia: a case study. MSc thesis, Dalhousie University, Halifax

Sutherland B (1997) Nature conservation on private land in Nova Scotia. Proc NS Inst Sci 41:77-89

Sutherland B (1998) Nature Trust projects: land conservation in action! Nat Landsc: the newsletter of the Nova Scotia Nature Trust 4

Taylor RB, Shaw J (2002) Coastal character and coastal barrier evolution in the Bras d'Or Lakes, Nova Scotia. Proc NS Inst Sci 42:149-181 